\title{
Techno-Engineering Education and the Railways in Colonial India
}

\author{
Debashis Mandal* \\ (Received 13 March 2015; revised 16 March 2016)
}

\begin{abstract}
Railways created huge demand for technical personnel in British India. With the expansion of railways, various technical institutions were also established during the second half of the nineteenth century. But there was strong discrimination towards Indians, in the field of educations and also in jobs. Indians were not allowed admission in engineering or upper subordinate courses till 1864 in Thomason Engineering College at Roorkey. But Indians demanded more sophisticated technical knowledge. Apart from the engineering colleges, railway workshops also developed as centres for learning or knowledge generation. In the paper, first, I will emphasize the role of railways for the development of engineering and workshop education in colonial India; second, discuss about the various kinds of discrimination in job and education opportunities, as integral part of the colonial policy for the Indians.
\end{abstract}

Key words: Discriminations, Engineering education, Public Works Department (PWD), Railways, Railway Workshop.

\section{INTRODUCTION}

Railway was the most important project introduced in Colonial India as a part of technology transfer from the industrialised West to the East. It created impact not only in the sphere of technology but also on the socio-economic and political cultural life of the people of the Indian subcontinent. Between 1853-1947, India had 40,000 miles of railway track and of these, 35,406 miles were constructed and opened by 1920 catapulting India to the position of world's fifth largest railway network and almost 5\% share of global route mileage. (Morris and Dudley, 1975 pp. 8-15)

The planning and execution of railway construction in India was relied exclusively on British civil and military engineers. Understandably this reliance on western science and technology, stemmed from the fact that, the market of international technology in that period was essentially dominated by Britain, USA, Belgium and Canada (Simmons, 1978 p. 176). During the 1840 s and 1850 s railways spread over the continent and the Americas, which has been described by the Eric Hobsbawm as 'in quantitative terms, the first real railway age' (Hobsbawm, 1977 p. 71). But later in the 1870s and 1880 s the technical pre-eminence of British railway engineers, emphasized a more hands on approach i.e. 'learning by doing' and their increasingly outmoded antipathy to theoretical, scientific training began to decrease, thanks to the new innovations field (Buchanan, 1983 pp. 407429). They felt that the theoretical knowledge which taught in Britain might not be properly applicable to new conditions or new geographical situations. Technologies were coming from

\footnotetext{
* Ph.D Scholar, Zakir Husain Centre for Educational Studies, School of Social Sciences, Jawaharlal Nehru University, New Delhi-110067; Email: deba.com@gmail.com
} 
Europe, not properly applicable to Indian field, topography and western technologies became dependent on the field prepared by indigenous methods, resulting in evolution or Indianisation of the transferred technology. This trend concretizes more from the 1860 s resulting in transformation and innovations in the field of engineering. The end result was the emergence of indigenous innovations and an engineering community. This was necessary for the British Government to reduce the dependency upon the British engineers or technical personnel for its cost effective measure.

For the supervision of railways construction in India during pre-1870s era, the commanding names of the British railway in India are Robert Stephenson and George Berkley for Great Indian Peninsula Railway(GIP), Isambard Brunnel for East Bengal Railway(EBR), George Perker Bidder for Scinde, Delhi, Punjab Railway(SDP), James and Alexander Rendel for East Indian Railway(EIR) and Jawn Hakshaw for Madras Railway (MR). These were engaged as consulting engineers by the London based private railway company boards (Derbyshire, 1995 pp.178-215). The early railway contractors were recruited through competitive bidding from Britain. However, some notably British Indian firms- Burn \& Co., Norris \& Co., on the EIR and Parsi contractor Sir Jamsetjee Dorabjee secured four contracts to build large sections of railway track.

I wish to show how the construction of railway in India created demand for the technical education. Prior to 1850 s India had only some survey schools, except Roorkey Engineering College. Students from these schools were helpful only for the surveying purpose or to connect the newly built empire (Edney, 1997) ${ }^{1}$. But the railways demanded more sophisticated technical knowledge with minimum cost. It will be interesting to discuss the discrimination against Indians in various railway jobs after getting even proper education.

\section{Demand for Engineering Education}

Against the colonial backdrop, education was always a political and economic pressure from the both from the points of view of colonizer and colonized. After the consolidation of an empire, during the second half of nineteenth century, the demand of trained technical personnel in India grew. Indians demanded more and more technical education. In the nineteenth century, the principal employer of the technically trained people was the Public Works Department (PWD). The activities of the Public Works Department was mainly divided into three branches - a) construction of roads, buildings and irrigation, b) State Railways, c) maintaining accounts.

The Industrial Revolution in Europe during the eighteenth and nineteenth century created major changes in in the field of agriculture, manufacturing, mining, transport and technology. This revolution introduced new elements in the concept of production, distribution, and laid the foundation of the techno savy civilization. This new societal structure, developments were purely based on science and technology. In global scenario trade expansion was enabled by the introduction of canals, roads and railways. Mechanization of small jobs, new inventions influenced the production procedures. The new developments and technological changes were constantly influencing the system of distribution and production and it was necessary to develop new learning system specially designed to meet the challenges of occupational needs in the

\footnotetext{
${ }^{1}$ For details see Mathew H Edney, Mapping an Empire: The Geographical Construction of British India: 1765-1843, University of Chicago Press, 1997. In this book author shows how imperial Britain used modern/western survey techniques to not only create and define the spatial of its newly conquered territory, but also legitimize its colonialist activities in India. It also offers new looks into the relationship between ideology, technology and politics.
} 
industry and maintenance of its products. So a new system of training, learning and skill development were required to supply the trained manpower for industry, railways, telegraph, navigation. Many manufacturing units came up which required unskilled as well as skilled labour. This European phenomenon also influenced the Indian economy and the politics of colonial government. India was not only the biggest supplier of raw cotton, it was also a huge market for the finished goods. Railways in India was the most important project within the British Empire, which attracted approximately 150 million pounds of British capital during the nineteenth century. But British government guaranteed 5\% return to the investor, which came from the Indian tax payers. As Lord Dalhousie argued '...the object of that experiment is to prove not only that it is practicable to construct railways in India as engineering works, but that such railways when constructed, will as commercial undertakings, afford a far remunerative return on the expend money' ${ }^{2}$.

In India to train the technicians, many technical schools were instituted. In 1840 an industrial school was established at Guindy, Madras, known as 'School of Ordinance Artificers' by Major Maitland, Superintendent of the Gun Carriage Factory. In the year 1842, James Thomason, the Lietenant of Governor of North western Province, proposed the establishment of a College of Civil engineering at Roorkey to train engineering personnel at various levels for public works of the country, particularly construction work of the Ganges canal (Dass, 1984 p. 2). Finally in 1847 , the first engineering college established at Roorkey, named Thomason Engineering College, and at the initial stage this college trained people for the irrigation works. This college trained mainly Europeans as upper subordinate class and Indians as lower subordinate class of engineering. The recruitment of every student was controlled by the Public Works Department and after completion of the course, the students were employed in Irrigation Department or any branch of PWD. Before that India had many technical schools and survey schools, which trained the surveyors for mapping the newly built empire (Edney, 1997). Probably first survey school was established at Madras in the year 1794 by some English traders (Sen, p. 189).

In India engineering education was introduced with definite objectives, but not similar to Western countries and it was evolved or decided not from below but organised from above (Kumar, p. 216). It was the part of political machinary started by the colonial government to map survey and consolidate the empire to achieve their economic as well political goal. Science and technology were the main weapons of the British Raj to control the imperial power. So in the initial stages government's aim was to produce some skilled personnel or labour with basic technical knowledge for the requirement of Public Works Department. But other European countries like France, Germany and in England introduced engineering education to accelerate the industrialization process. In India, it was intended to meet the needs and requirements of the Colonial government (Forbes, 1975 p. 78). So the British introduced the Public Works Department to fulfill their specific needs, for example, to convert India into a major supplier of raw materials for Europe and British colonies overseas and to ensure the flow of British manufactured goods to India (Bagal, 1955 p. 110). As per requirements, construction of roads and railway, producing surveyors and engineers were necessary for the colonial rule, only not from an economic point of view but also for political and administrative as well as military and strategic reasons (Bagal, 1955 p. 146). More or less until the middle of the nineteenth century, the British through the East India Company engaged themselves in expanding political domination in the Indian subcontinent and

\footnotetext{
${ }^{2}$ Extracts from the Dalhousie Minutes, $4^{\text {th }}$ July, 1850, PWD (Railway) Proceedings, $2^{\text {nd }}$ august, 1850, Nos. 39-51
} 
Table 1. Pioneering technical colleges in nineteenth century India

\begin{tabular}{|lll|}
\hline Year of Establishment & Name of College & Branch \\
\hline 1847 & Thompson's Engineering College, Roorkee & Civil \\
1856 & Calcutta College of Civil Engineering & Civil, Mechanical \\
1858 & Poona College of Engineering & Civil \\
1887 & Victoria Jubilee Technical Institute & Electrical, Mechanical \\
\hline
\end{tabular}

with this political domination, Britishers also tried to consolidate their position. For communicating within the vast empire, river, canal system or telegraph were not enough. Then railway became the most powerful tool of the British Raj. In 185455, Department of Public works was established, with the expansion of its activities the British required trained staff in subordinate ranks on large scale especially when they introduced railway in India. So this paper tries to focus on how the introduction of railway (as part of the PWD) influenced the development of technical or engineering education in India. During the Sipahi mutiny of 1857 railways as medium of communication was used most and proved its efficiency. But after the shocking experience of the mutiny, the British had to rethink their policy towards India.

The Thomason Engineering College (1847) or The Roorkee Engineering College provided different curricula for different types of students; an engineering class for domiciled Europeans and a few Indians, an upper subordinate's class to trained British noncommissioned officers and soldiers for the lower job of overseer for the Department of Public Works, and a lower subordinate's class to train Indian surveyors (Headrick, 1988 p. 317; Mittal, 1886, pp. 28-29). Till 1856, out of a total of thirty one engineers passing out, eight were English army officers (1854-56), sixteen Europeans or Anglo Indian civilians and seven Indians (Mittal, 1886 , p. 85). With the introduction of railways, the demand also increased for trained engineers. The course of study in Thomason College comprised of six subjects: mathematics, civil engineering, surveying, drawing, science, Hindustani (local Language). Under the civil engineering courses, they had to study building materials, earthwork, carpentry, bridge buildings, roads, railway, irrigation, special construction, applied mathematics, mechanism, estimating, and project (Mittal, 1886,p. 87). In the year1853, Madras Government also urged East India company to establish a school for training youths for civil engineering in the Presidency. The Dispatch of the East India Company to Madras Government, No.10, dated $30^{\text {th }}$ December, 1853 wrote:

'... The educated youth of India should be
encouraged to direct their attention and studies to
branches of civil engineering with a view to their
employment in the existing railway works which
will for many years to come be carried on in that
country and we shall be glad to learn that the East
Indian Railway Company had established a school
similar to one initiated to Madras for the purpose
of introducing native engineer into their service's.

In 1854, a school for the training of overseers was established in Pune. 'Poona Engineering College and Mechanical School' to train the subordinate officers for carrying out public works like buildings, dams, canals, railways and bridges. Later on school became the 'Poona Civil Engineering College'. In the same year famous educational document was submitted to the British Government known as 'Wood's

\footnotetext{
${ }^{3}$ Education, Schools, Establishment by East Indian Railway Company of Engineering School similar to that at Madras desired, British Library (BL), IOR/Z/E/4/24/E274: 1853-1854, pp.286-288.
} 
Dispatch'. This famous Dispatch emphasized an 'Enlarged System of Education to be pursued in India' or occupation based education system. According to this recommendation, Lord Dalhousie suggested to the Court of Directors the need for establishing of an engineering class at each Presidency (Sedwal, 2008 pp. 495). In 1856 the Presidency College, Calcutta started a department of civil engineering, which later bloomed into Sibpur B.E. College in 1880. During this period the classes of the Presidency College played the most important role for the training of the engineers. S.F. Downing, Principal of the Presidency College Observed:

\begin{abstract}
I have learned from conversation with respectable educated natives that the fact of the department belonging to the Presidency College gives it certain status in the eyes of the native society; consequently a superior class is attracted to it than would be the case were a school attached to large government... This appears to me to be an important point, because native Assistant Engineers, Public Works Department, have to associate officially with English gentlemen, and consequently the former ought, if possible, to be recruited from the upper middle class community ${ }^{4}$.
\end{abstract}

In 1858 an initiative was taken by $\mathrm{Mr}$. Taylor, the Judge of Mymensingh, to establish an industrial school in Patna(Bihar). This proposal was very important in the field of technical education in India. In this college Mr.Taylor wanted to offer a agricultural training school and a institutions for cattle breeding and primary school with the engineering college ${ }^{5}$. The Surveyor School in Madras, dating back to 1794 , became the Madras Civil Engineering College. Like the Thomson College, they offered both civil engineering courses for higher level, and in lower level training for lower subordinates, surveyors, and draftsmen. After the 1857 rebellion, Public Works Department expanded very fast to meet the demand of the colonial regime. But the students of four engineering colleges were not able to cater to these demands. To fill the gap, the Indian office recruited young engineers in Britain and sent them to Roorkey for further training. They were called 'Stanley Engineers (Mittal, 1886, p. 67) after Lord Stanley who was then Secretary of State for India and Sir P.T.Cautley ${ }^{6}$ was the main author of the scheme. These men however, failed, to live up to the expectations, Colonel George Tomkyns Chesney, first Accountant General of PWD rued:

\begin{abstract}
The present mode of training an engineer, where a young man pays a fee to a civil or mechanical engineer for permission to work in an office or workshop, and pick up such crumbs of knowledge as fall in his way, is not education, and the case must be rare where persons after undergoing such a training, will be found able to pass an examination involving any knowledge of the principles of mathematics or theoretical mechanics. They usually take no knowledge of the subject into the office and gain none there. ... Thus the result of the present system is, that we are not getting engineers, and that the qualifications of the persons who do enter the service in this way may be of the slenderest kind (Chesney, 1870 pp.3-4).
\end{abstract}

In the given situation, the Public Works Department had one last option, in Chesney's words, 'it seemed plain that the only course open to the government was to revert to its original intention, and to take the preparation of the candidates under its own supervision (Chesney, 1870, p.7). In view of the huge demand of engineers in India, in the year 1870 the Duke of Argyll, the Secretary of State for India, appointed Chesney to found the Royal Indian Engineering

\footnotetext{
4 'Note by Mr.S.F.Downing, Principal of the C.E.Dept. of the Presidency College', in Technical Education in Bengal: Selected Papers from the Records of the Bengal Secretariat, Public Works Department, compiled by Mr. F.J.E. Spring, Under Secretary, PWD, Calcutta, 1886, BL, IOR/V/27/865/5.

${ }^{5}$ Bengal Education Department correspondence regarding Patna Industrial Institutions, 1858, Calcutta, B.L., IOR/V/27/865/9 and $\mathrm{IOR} / \mathrm{L} / \mathrm{PJ} / 3 / 1036$.

${ }^{6}$ Cautley was one of the fifteen members of the Council of India, constituted in 1858 to advise the Secretary of State for India. He was also famous for the creation of Ganges Canal and associated with James Thomason for the establishment of Roorkey College.
} 
College at Coopers Hill near London. It opened in August 1872 with 42 students (Headrick, 1988, p. 320). It supplied engineers to the Indian Telegraph Department in 1878 and later the traffic Department of the Indian State Railways and the Accounts Branch of the PWD. From 1887 officers of the Indian Forest Service were also recruited after a course of training partly at this college and partly on the European continent ${ }^{7}$. In between 1872-1903(when it closed), 1623 men graduated from this college and of these 1010 served in India, and among these 764 served in Public Works (Headrick, 1988 p. 321).

\section{RAILWAY WORKSHOPS}

In 1904 sanction was made for the establishment of a Technical School at Lilloah (Howrah Workshop) for the benefit of the Railway apprentices $^{8}$. It was open for the apprentices of the engineering and carriage and wagon departments. It started with 20 students and granted one master post with allowance of Rs.50/per mensem and with monthly contingency Rs. 20 . Every mechanic who attended the school had to pay Rs.4/- per mensem 9 . Opening of this technical school was very necessary for the government. In a letter clearly stated that:

The training in the Technical School is intended to give the apprentice lads a sound theoretical knowledge of at least the rudiments of their trade, and the chief Engineer and the Carriage and Wagon superintendent concur in the opinion that any expenditure incurred by the Company in connection with such training will be direct benefit to the Railway, and that the Technical School has been of considerable benefit to the apprentices of their departments and through them to the company $^{10}$.
For the regular upkeep of the railway equipment and training, the railways built workshops in major stations throughout the India, such as at Parel near Bombay, Lahore in Punjab, Jamalpur in Bihar, and Kharagpur and Kanchrapara in Bengal. These workshops came into different proportions: massive complexes of building and heavy machinery of needed for major repairs of locomotives and for rolling stocks construction, where thousands of people laboured daily. These workshops complexes were significant for many reasons. They were the early centres of the heavy engineering industry in India; they were crucibles of engineering transfer; they employed substantial members of people in ways that significantly affected local economies, they were in short, essential to the railroads and affected the making of modern India in many dimensions (Kerr, 2007, p. 84). The workshop at Lahore was established in the early 1860s and in the year 1886 amalgamation took place in between North Western State Railways and Railways of Punjab, Sind. Then the Lahore workshop was catapulted into pivotal position, repairing locomotives and building and repairing carriages and wagons for a far-flung network whose route miles totaled nearly 2000 (Malika, 1962 pp.1-21; Kerr, 2007 pp. 231275 ). During the 1890 s nearly 4000 men worked in Lahore workshops and in 1905, it increased to 63,000 employees with a system of repairing 756 engines, 2,399 coaches, and 11622 goods vehicles (Kerr, 2012, p. 191) ${ }^{11}$. Jamalpore (eastern Bihar) workshop established in 1862 was the East Indian Railway's main workshop, where daily employment was 3,000 in the year 1891. In the year 1888 a special technical school started within the workshop and they also started mechanical

\footnotetext{
${ }^{7}$ Letter from the Under-Secretary of State to President, Cooper's Hill College, dated $11^{\text {th }}$ October 1906, Proceedings of the P.W.D. Establishment, January 1907, nos.93-103.

${ }^{8}$ Proceedings of the PWD, Railway Establishment Branch, July-1904, No.59B, p.4.

${ }^{9}$ Proceedings of the PWD, Railway Establishment Branch, July-1904, No.59/2 B, p.7.

${ }^{10}$ Agent's letter no. 33, dated $10^{\text {th }}$ march, 1904, Proceedings of the PWD, Railway Establishment Branch, july-1904, No.59/3 B.

${ }^{11}$ Administration Report on the Railways in India for the Calendar Year 1905, London, 1906, P.84 \& P.100, cited in Ian J Kerr, Engines of Change: The Railroads That made in India, Orient Black Swan, New Delhi, 2012, p.191.
} 
engineering classes (Kerr, 2012, p.90) ${ }^{12}$. All these workshops became the main training center for the railway men and the process of Indianisation of all services was started with these workshops. In 1875 various railways- the East Indian, the Oudh and Rohilkund, and the Scinde, Punjab and Delhi started apprenticeship programs to train European, Eurasian and some Indian boys to become foremen, fitters, engine erectors, and locomotive drivers.

All these colleges and workshops provided broad ranging instruction in all aspect of engineering, coupled with geography, language and history of the subcontinent, as well as technical practices and modes of working best suited to Indian conditions. This served to imbue graduates with an engineering perspective significantly different from that of the ordinary, company line, British recruit. This was a paradoxical situation in Indian education systems. In the year1800, Fort William College was established at Kolkata to train British officers with Indian norms and languages to better govern India. During the second half of the nineteenth century demand increased not only for technical education but also for technological knowledge. Britishers established technical institutions but Indians were getting only basic level of technical training, not knowledge. Slowly the situation changed, Indians demanded a superior knowledge and jobs in superior position. In addition with the India oriented expertise community emerged and the support for intellectual infrastructure of professional societies and technical journals began to develop. They started sharing their own work experiences, ideas, adoption of suitable technical method, not only within the Indian continent but with also outside world. James Berkley established the First professional body in the early 1850 s in Bombay. In 1858 C.C. Adley started a technical journal in Calcutta, 'Engineers Journal and Railway Chronicle of India and Colonies', which was circulated throughout India (de Souza, 1958 pp.3-5). The aim of this magazine was to circulate knowledge about the recent technological developments in other presidencies, as well as back in home (Britain). In 1886, this journal changed its name and known as 'Indian Engineering'. By the 1895 circulation of this journal reached up to Japan and again changed its name as 'The Indian and Eastern Engineer'. Even these India based engineers attended meetings in their home institutions, dealing with technical aspects of their work in the subcontinent (Darbyshyre, pp. 207) ${ }^{13}$. Obviously India's scientific and technical achievements were reflected in the pages of this journal. This created some sort of an association for the Indian scientific community and also helped to build separate scientific identity apart from the West.

\section{Job Discrimination}

During the second half of the nineteenth century India witnessed establishment of various institutions with the expansions of PWD's work. But after the training, the questions come automatically in mind where these trained people were to be absorbed? What kind of jobs they were getting? What were their statuses?

In a dispatch to the Military Board dated $17^{\text {th }}$ January 1845 , it was stated:
... the Lt-Governor (James Thomason) has long been anxious to raise up a body of native civil engineers, who might materially aid the efforts of

\footnotetext{
${ }^{12}$ The Spirit of Jamalpur-cradle of IRSME, 75years of Indian Railways Service of Mechanical Engineers: 1927-2002, Govt. of India, 2002

${ }^{13}$ Fifty seven major papers published in the annual volume of Minutes of Proceedings of The Institution of Civil Engineers, between 1861-65, five were on Indian topics by engineers working in the subcontinent, including three on rail related matters. Between 1901-05, six out of 91 major papers were on Indian subjects, three of which related to railways. This reference quoted from Ian Darbyshyre, 'The Building of India's Railways'.... in Technology and the Raj, edited by RoyMacLeod \& Deepak Kumar, op.cit. P.207.
} 
the officer in charge of canals in the operation of surveying and leveling, and laying out water courses, as well as preparation of maps and plans, and formation of estimates ${ }^{14}$.

In July 1845, the Secretary of the Government of North-West Provinces wrote to the Home Secretary for incorporating natives in engineering service:

Their skills in mathematics and expertness with which they acquire mathematical knowledge of all sorts is well known. Their expertness in arithmetical calculations is also notorious ... there can be little doubt the pupils in the colleges will quickly turn their attention to the subject, if only adequate arrangement be held out to them, in the form of remunerative employment hereafter ... when the young men are assured that the attainments of a certain proficiency will secure them a good situation and respectable position in life, there are many who will exert themselves to reach the standard ${ }^{15}$.

With this view, $\mathrm{J}$ Thomason drew up a scheme for the examination and future employment of the natives as Sub-Assistant Executive Engineers, but Governor-General canceled $i^{16}$. So after the establishment of Thomason College we find this kind of official policy and as usual the upper subordinate class maintained Western military character till 1864. In the upper subordinate class generally Indians were not allowed to take admission. From the beginning of 1849 to 1865 , the number of passed out students in the upper subordinate class were 336 and out of these number, only 4 were Indian (Mittal, 1886 p.90). These four students belonged to the batch of 1862, which may be explained as an experiment to see whether the Indians were capable or not. From 1865 onwards, progressively open up the class for Indian students and the number of Indian students sharply increased. From 1869 to 1873,61 Indian students out of 71 were passed. But in between 1876 and 1895, 211 engineering students from the Thomason College, of whom 139 were Englishmen (or rather AngloIndian) and 72 were Indians. It shows that Indian students gradually caught up with their Western counterparts. Nine times in these years (18761895), Indians topped the list of successful candidates ${ }^{17}$.

The policy of employing Europeans was costly. European locomotive drivers in India were paid three or four times the wages of drivers in England, or about ten times as much as their Indian counterparts. In 1853, it had been stated in the House of Commons that the universal rule and practice in Indian administration would be 'native agency and European Superintendence'(Dodwell, 1929, p.362) and after the 1857 rebellion no Indians were admitted in the higher ranks of the railway department or any other government services. Though in 1878-79, a Select Committee of the Parliament reduced the number of European railway employees as a means of lowering state railway maintenance. There was also another myth that the Indians were not capable to master technical works, especially in railway position like engine drivers or higher position jobs. Juland Danvers, the Govt. Director of Indian Railways in 1877 , wrote -'It will take time to qualify them for the more arduous duties of locomotive drivers, which require coolness, courage, and decision' (Danvers, 1877 p.39). But he continued, 'a certain proportion of European officers and servants will always be necessary' (Danvers, 1877, p. 39).

\footnotetext{
${ }^{14}$ Mr.Thomason's Dispatches, Vol.1, Baptist Mission Press, Calcutta, 1858, p.383, BL, IOR/V/23/133.

${ }^{15}$ Proceedings of the Home Department, Public Branch, 13 September, 1845, Part-A, Nos. 19-30, p.3, National Archives of India, New Delhi

${ }^{16}$ Proceedings of the Home Department, Public Branch, 13 September, 1845, Part-A, Nos. 19-30, p.55, National Archives of India, New Delhi

${ }^{17}$ They were K.C. Bandopadhyay (1876), Fakir Chand (1884), Ralla Ram (1886), Chandu Lal (1887), Chandu Lal (1889), B.B.Chakravarti (1890), N.K.Mitra (1891), Chote Lal (1893), K.C.Patrick (1895), KC Bandopadhyay (1876), cited in History of Thomason College, op.cit., pp.114.
} 
Though he admitted that 'some had already shown themselves to equal to such employment...' (Danvers, 1877 p.41). In 1874 P.W.D. resolution said:

\begin{abstract}
Natives who can manage a steam engine have, for many years, been found in the presidency towns. There are even now a few natives capable of driving locomotive engine, though many engineers of experience express doubts whether the nerve and readiness of mechanical resource required to make a good driver are likely to be found largely amongst the native of India ${ }^{18}$.
\end{abstract}

The memorandum of the PWD in 1880 said that the native people aspiring for a PWD job, after acquiring elementary knowledge of drawing and geometry should be sent to government factories or on the work to prove his capabilities as 'Engineer of Men'. Subsequent to that, further education would be provided by the state $^{19}$. So it shows that Britshers always doubted the capability of Indian people to take this kind of heavy education both physically and mentally. But discrimination did not end. The famous Marathi newspaper, Kesari wrote after a railway accident on $4^{\text {th }}$ July 1899 :

...the fact that European driver, whose reckless conduct while in charge of a train led to the loss of lives was acquitted, while an innocent native Station Master and his assistant, whose conduct did not lead to any serious consequence were sentenced to rigorous imprisonment, plainly shows whether the British rule is founded on justice or might. In the case of Europeans even high salaried judges are held incompetent to judge the accused and he enjoys the birthright of being tried by a jury wholly composed of his own countrymen; while a person of dark skin, however high in rank or position, is liable to be tried by any Magistrate, who may be puppet in the hands of the government. What does this mean, if not a race distinction? ${ }^{20}$
In 1900, 61 students were enrolled in Jamalpore for East Indian Railway apprenticeship program among them 40 were European and Eurasians who were accommodated in company hostel, while the 21 Indians arranged their own accommodation (Lehmann, 1977 pp.49-61). It is true that caste factor in the Indian society was also a big issue, for staying together in a hostel accommodation. This kind of racial discrimination was widely prevalent at that time. There was a big difference in the salaries of the Indian and European trainees. The Locomotive superintendent of Great Indian Peninsula, Bombay wrote- 'Well of course that is a question of market value. They may pass the same examination, but whether you get the same work out of them ... there are different market values for both classes, the one can live on Rs.35/- a month, while the other cannot. Don't you think that this should be taken into consideration?'21

The educated Indians were well aware of this kind of discrimination based upon racism. Not only in jobs but in education sectors Indian were not provided proper knowledge to acquire high post. In the technical institutions mostly lower subordinate classes were open for the Indians. As late as 1832 Balshastri Jambhekar (founder of Bombay Durpan, Marathi-English magazine from Bombay) expressed his opinion on the pages of Bombay Durpan - 'the cruelty and injustice of prosecuting a whole nation from every station of trust, rank or emolument, and affixing upon them the stigma of unworthiness which experience has shown to be undeserved'22. Famous Indian scientists in the colonial regime like P.C.Ray, J.C.Bose and geologist P.N.Bose had to struggle

\footnotetext{
${ }^{18}$ Resolution by the government of India, Public Works Department: training of Natives as engine Drivers, mechanics, and plate layers on state Railways, Fort William $4^{\text {th }}$ June 1874, in Technical Education in Bengal, op.cit. pp.85-86.

${ }^{19}$ Proceedings of the PWD, Railway Branch, June 1880, No.135 B, NAI.

${ }^{20}$ Office of the Reporter on the Native Press, New Secretariat Bombay, 11 ${ }^{\text {th }}$ July, 1899, BL, IOR/L/PJ/6:1899.

${ }^{21}$ Indian Industrial Commission, 1916-18, Superintendent of Govt. Printing, Calcutta, 1918.

${ }^{22}$ The Bombay Durpan, 13 April, 1832, cited in Deepak Kumar's, 'Racial Discrimination and Science in Nineteenth Century India', Indian Economic and Social History Review, Volume- XIX, No.1, pp.63-82
} 
throughout their life against this kind of discrimination $^{23}$.

Apart from the discriminations in jobs native passengers were also treated poorly. For the safety reason, all the third class passengers were locked in waiting rooms, to prevent their tendencies to board trains before it stopped. This practice was very humiliating to Indians and after the criticism in newspapers and written applications to railway authority was compelled to stop the practice ${ }^{24}$. It is very true that British officials believed that the Indians would never become competent or trustworthy officer. The Railway Gazette observed:

... It is unfortunately true that the efforts to turn the young native into a competent and trustworthy engineer or traffic man have to be large extent been a failure. By trustworthy, of course, is understood not only incorruptibility, but being able to assume responsibility and capacity to act in an emergency and in all these qualifications the average nativeand often the Eurasians- is usually lacking., ${ }^{25}$

The Railway Gazette also criticized the education system that was not sufficient to build good character of the natives.

\section{Conclusion}

During colonial rule in India, technical education was not impartial and partisan measures were enforced to meet the growing demand for craftsmen, engineers and skilled workers. The government policy was directed to meet the needs of the colonial economy and to provide educational infrastructure, based on their own policy and requirement. So in higher technical education there was dearth of good number of educated Indians. Main objective of any project was to prove the superiority of Europeans and their 'civilizing mission'. Education however does not mean the necessity of meeting the existing demands and to prepare youths for the future and to create knowledge based society. The demand thus increased from the first half of the $20^{\text {th }}$ century for more technical education especially during the Swadeshi Movement. The nationalists outlook for technical education was however, to prepare for the future by training men to replace the Europeans and create a new economy and the railway was expected to accelerate this process in India. The Britishers on the other hand believed that their efforts of turning young natives as a competent and trustworthy engineers or traffic men was to large extent a failed project. They also believed that being trustworthy, taking responsibility, capacity to act during the emergency, etc. were lacking not only among the natives but also among Eurasians. Ninety nine percent of the railway clerical staffs were native Indians but there was serious shortage of good mechanics in the workshops. A costly education system and not getting proper jobs were responsible for these problems.

The early period of railway may not be directly related with the establishment of many engineering colleges for Calcutta, Madras, Pune, Roorkey. The people educated in these colleges were however appointed in the railways and their practical training also took place in the railway at times with special courses on railway and bridge building. Later when the workshops began to be established for maintaining railway, rolling stocks, it created greater impact on the development of technical education and also on industrial economy of India.

\section{BibliOgRAPHY}

Administration Report on the Railways in India for the Calendar Year 1905, London, 1906, P.84 \& P.100, cited

\footnotetext{
${ }^{23}$ The Bombay Durpan, 13 April, 1832, cited in Deepak Kumar's, 'Racial Discrimination and Science in Nineteenth Century India', Indian Economic and Social History Review, Volume- XIX, No.1, pp.63-82

${ }^{24}$ The Railway Gazette, May 28, 1913, London, p.1.

25 The Railway Gazette, May 28, 1913, London, p.1.
} 
in Ian J Kerr, Engines of Change: The Railroads That made in India, Orient Black Swan, New Delhi, 2012, p.191.

Agent's letter no. 33, dated $10^{\text {th }}$ march, 1904, Proceedings of the PWD, Railway Establishment Branch, july1904, No.59/3 B.

Bagal, J C. Pramath Nath Bose, Pramatha Nath Bose Centenary Celebration Committee, New Delhi, 1955, p. 110 .

Bengal Education Department correspondence regarding Patna Industrial Institutions, 1858, Calcutta, B.L., IOR/ $\mathrm{V} / 27 / 865 / 9$ and IOR/L/PJ/3/1036.

Buchanan, R A. 'Gentlemen Engineers: The Making of a Profession', Victorian Studies, vol.26, No.4, 1983, pp.407-429.

Chesney, G. 'The Civil Engineering College for India', dated India Office, October7, 1870 in B.L., India Office Records, L /PWD/8/9, pp.7.

Danvers, Juland. Indian Railways:Their Past History, Present Condition, and Future Prospects, Effingham Wilson, 1877, P.39, B.L., IOR/V/27/720/2.

Dass, Dayal. Development of Technical education in India, Ministry of Education and Culture, New Delhi, 1984, p. 2.

de Souza, P N. 'The Indian and Eastern Engineer', The Indian and Eastern Engineer, Centenary Number, December, 1958, pp.3-5.

Derbyshire, Ian. 'The Building of India's Railway', in Deepak Kumar and Roy Macleod (eds.) Technology and the Raj, Western Technology and Technical Transfers to India: 1700-1947, Sage Publication, New Delhi, 1995, pp. 178-215.

Dodwell, H H. The Cambridge History of the British Empire, Vol.2, Cambridge University Press, 1929, p.362.

Edney, Mathew H. Mapping an Empire: The Geographical Construction of British India: 1765-1843, University of Chicago Press, 1997.

Education, Schools, Establishment by East Indian Railway Company of Engineering School similar to that at Madras desired, British Library (BL), IOR/Z/E/4/24/ E274: 1853-1854, pp.286-288.

Extracts from the Dalhousie Minutes, $4^{\text {th }}$ July, 1850, PWD (Railway) Proceedings, $2^{\text {nd }}$ August, 1850, Nos. 39-51.

Forbes, G H. Positivism in Bengal, Calcutta, Minerva Associates, 1975, p.78.
Headrick,Daniel R. The Tentacles of Progress: Technology Transfer in the Age of Imperialism, 1850-1940, Oxford University Press, New York, 1988, p.320.

Hobsbawm, Eric. The Age of Capital, 1848-75, Abacus, London, 1977, p. 71.

Kerr, Ian J. The Spirit of Jamalpur-cradle of IRSME, 75years of Indian Railways Service of Mechanical Engineers: 1927-2002, Govt. of Inda, 2002.

Kerr, Ian J. Engines of Change: The Railroads that made India, Prager, Westport, 2007, P.84.

Kerr, Ian J. 'The Railway Workshops and Their Labour', in 27 Down: New Departures in Indian Railway Studies, edited by Ian J Kerr, Orient Longman, New Delhi, 2007, pp.231-275.

Kumar, Arun. 'Colonial Requirements and Engineering Education: The Public Works Departments', 18471947 in Deepak Kumar \& Roy Mcleod (eds.), Deepak Kumar and Roy Macleod (eds.) Technology and the Raj, Western Technology and Technical Transfers to India: 1700-1947, Sage Publication, New Delhi, 1995, p. 216.

Lehmann, Fritz. 'Railway workshops, Technology transfer, skilled labour recruitment in Colonial India', Journal of Historical Research, 20, No.1, August-1977, p.4961.

Malika, M.B.K. Hundred Years of Pakistan Railway, Ministry of Railways and Communication, Karachi, 1962, pp.1-21.

Mittal, K V. History of The Thomason College of Engineering (1847-1949), University of Roorkey, Roorkey, 1886, pp. 28-29.

Morris, Morris David and Dudley, Clyde B. 'Selected Railway Statistics for Indian Subcontinent (India, Pakistan, Bangladesh), 1853-1946-47', Artha Vinjan, 17, 1975, Table 1 and 2, pp.8-15.

Sedwal, Mona. 'Technical Education in India: From Past to present', in R Hariharan (ed.), Recent trends in Technical Education, MacMilan, Delhi, 2008, p.495.

Sen, Biman. 'Technical Education in India: 1921-80', in P.R.Panchamukhi (ed.), Studies in Educational Reforms in India, Vol.3, Part-2, Bombay, Himalaya, P.189.

Simmons, Jack. The Railway in England and Wales: 18301914, Leicester University Press, Leister, 1978, Vol.1, p.176. 